\title{
Study on the Path of Specialization Construction of "Management" Course under the Background of Applied Curriculum Reform
}

\author{
Jiaojiao Mo \\ Xi'an Peihua University, Xi'an, Shaanxi, 710125
}

Keywords: applied course; Curriculum Reform; Management; curriculum specialization

\begin{abstract}
It is the key to transform the local colleges and universities to the applied technology colleges and universities in order to meet the needs of the development of the new era, to improve the application of talents 'knowledge, the technical ability and level, and to accelerate the deepening of the construction of applied courses, in order to improve the quality of personnel training, to improve the level of local universities. This paper first analyzes the connotation and characteristics of the applied curriculum, then analyzes the present situation and the existing problems of the course of management, and finally attempts to explore the path of the construction of the characteristic of management under the background of the applied curriculum reform.
\end{abstract}

\section{Introduction}

Curriculum is a cell of a major. Curriculum construction is at the core of teaching infrastructure. The level, quality and achievement of curriculum construction are the important signs to measure the school running level and teaching quality. Therefore, it is necessary for colleges and universities to deepen curriculum reform under the background of the Applied Curriculum Reform, the construction of applied courses should be accelerated in the process of transformation and development of local colleges and universities. The traditional classroom teaching is not effective, too theoretical, ignoring students' practical ability, it is difficult to improve students' knowledge transfer and application ability, and cannot effectively achieve the teaching objectives. The effectiveness of the high course is to achieve the goal of knowledge, ability and quality. It is necessary for the teacher teaching the Management to reform.

\section{The connotation and characteristics of the applied curriculum}

\subsection{The connotation of the applied curriculum}

The applied university is a kind of higher education which is chosen in the development of the new local undergraduate colleges and universities. It specially trains applied professional talents with certain theoretical foundation, theoretical application and technical ability, to serve regional economic and social development for the face. The orientation of the applied university is regional and professional, the construction of discipline and specialty has the orientation and locality of profession, occupation or technology, the curriculum system focuses on the cultivation of applied ability, and the teaching staff highlights the applied characteristics. The main characteristics of the transformation from local colleges and universities to the implicit development are the improvement of quality and benefit, and the implicit development of curriculum is the endogenous curriculum development paradigm, which emphasizes the quality and benefit of courses. Speeding up the construction of applied courses in applied technical colleges is an important development mode to improve the quality and efficiency of courses.

\subsection{The characteristics of the applied curriculum}

The word "application" has a close relationship with the words "use", "practicality" and "applicability", and is inseparable from the meaning, object, level and scope of the expression. In the Dictionary of Contemporary Chinese, edited by Shanghai Dictionary Publishing House, it is 
interpreted as: "use", directly used in life or production, such as the application of new technology, applied science and so on, we can talk about the application according to the post, the operation link, the application for the industry, the application for the industry development, even about the life or the life can also talk about the application. The core of the concept of "application" is function and efficacy, which is inseparable from tools and resources, so application is instrumental and resourceful. Therefore, the application-oriented curriculum has the characteristics of tool and resource, and the core is that the students who study the course can finally apply the knowledge.

\section{The current situation and existing problems of the course of "Management"}

There are some problems in the course of management teaching, such as backward teaching mode, single teaching method, lack of encouragement in examination mode, lack of practical items, and so on.

\subsection{Backward teaching mode}

Most Management classes are still centered on teaching materials, teachers as the main body, feeding and irrigation as the main characteristics, and the following characteristics are highlighted: teachers explain more, students think less, teachers and students have less interaction. There are almost no exploratory problems, paying attention to the memory of knowledge, ignoring the transfer and application of knowledge, and even some teachers follow the book, the effectiveness of the classroom is poor, the curriculum has more explicit resources, ignoring the construction of hidden resources. Students' interest in learning is not high and the desire to actively explore knowledge is not strong, so it is difficult to achieve the curriculum goal of the Management.

\subsection{Single teaching method}

The traditional teaching method of the Management is simple, which is mainly taught by teacher talks about theory. Students do not know what the teacher wants, let alone what they want, so they can only listen to the teacher passively. Teachers do not know how well students learn. Teachers can only accomplish their task of teaching in a one-size-fits-all manner. When students do not, teachers can easily blame students, but cannot make plans and take measures according to students' actual situation. In class, teachers accomplish their own task of "teaching", not the task of students "learning". Students are bystanders of learning. They are not responsible for their studies. The teacher is exhausted and the students are tired of learning.

\subsection{Lack of encouragement in examination mode}

The course of Management is mainly determined by the final examination before the curriculum reform. The examination method is mainly examination-oriented, lacking of supervision and management of the process, lacking of encouragement, and unable to guide students to strengthen their daily study. It cannot effectively urge students to complete different tasks before, during and after class, nor can it stimulate students' motivation of self-constructing knowledge system, so that students cannot study hard to pursue the knowledge.

\subsection{Lack of practical items}

It cannot help the students get the experience of educational practice before the curriculum reform, the case teaching in the classroom cannot reflect the true meaning and implication of the educational practice, and the practical items of the curriculum are lacking. With the need of practical curriculum reform, it is necessary to strengthen the setting of practical links.

\section{The path of characteristic construction of management course under the background of Applied Curriculum Reform}

The construction trend of curriculum characteristics is inevitable under the background of application-oriented curriculum reform. In the course of "Management" teaching, teachers need to 
innovate the concept of curriculum design, which can be achieved through a variety of teaching methods, optimization of teaching content, construction of curriculum resources and reform of curriculum assessment form, etc. It can stimulate students' learning initiative, enthusiasm, connect with enterprise resources, train and improve students' knowledge ability, innovation ability and practical application ability, so as to effectively improve the teaching effect of curriculum and realize the course goal.

\subsection{To innovate curriculum design concepts}

It emphasizes the professional, practical and open nature of the basic course in the course design of Management, paying attention to cooperate with enterprises, organize teaching according to the project-oriented operation mechanism of "vocational post and post demand ability", paying attention to students' ability of "applying learning to use", and promote learning with "use". Students are the main body of study and encourage the development of students' professional ability and strengthen the cultivation of innovation ability and consciousness in the course of "Management". In the course design of "Management", we should not only consider the training of students' vocational skills, but also pay attention to the formation of comprehensive professional quality, so as to lay a good foundation for the sustainable development of students.

\subsection{To Diversify teaching methods}

It is necessary to flexibly use a variety of teaching methods, in the use of teaching methods emphasis on heuristic guidance, cooperative learning, real experience, step-by-step approach, task teaching method, case analysis, group discussion method, management of the game method, project teaching method, A variety of teaching methods, such as situational simulation and role-playing, have developed from classroom learning to network learning, making curriculum learning open. Improve students' ability of teamwork and innovation through cooperative learning and discussion of practical problems.

\subsection{To optimize curriculum content}

To optimize the content of management course, the course content is designed into seven modules (organization and management, management thought, management ethics and social network of organization, management environment, strategic management, innovation management). Each module has two practical projects, with a total of 16 practical projects, the knowledge points under each module match a classic case, the teaching content is specific and operational, presents the three-dimensional knowledge, easy for students to understand and digest.

\subsection{To attach importance to the construction of curriculum resources}

The course of "Management" not only needs to pay attention to the construction of explicit curriculum resources, including case base, exercise database, course video material, etc. under the background of applied curriculum reform. At the same time, teachers also need to pay attention to the development and utilization of hidden curriculum resources in the course of "Management", which is not limited to "preaching, teaching, and resolving doubts", which inevitably neglects the practice of students' emotional attitude, value concern and ideological and moral cultivation. It is necessary for teachers to organize and arrange teaching activities in a potential way by changing the teaching goal of "student subject personality standard".

\subsection{To reform curriculum assessment}

The novelty of the teaching contents and the advanced nature of the educational objectives will inevitably require more diversified, scientific and rational assessment methods. In view of the main problems existing in the traditional assessment mode of curriculum, the principle of the reform of the course assessment mode of "innovative design method" is: strengthen the process assessment, take the ability training and improvement as the leading thought, forming a pluralistic process assessment system to measure the students' learning situation, to realize the diversification of the examination forms, to turn the assessment time into a whole process, to make the examination 
contents scientific, to make the assessment information transparent, and to attach importance to the cultivation of the students' application ability and innovation ability. The examination system, which can promote the students' study and test the students' learning effect, is a pluralistic examination system, which is participated in by teachers, students and enterprises, and encourages the students to pursue the perfect dynamic examination, to pay attention to the composition of random assessment of learning process in peacetime.

\subsection{To joint Enterprise Resources Cooperation in Teaching}

The real working process of the enterprise develops the teaching design, establishes the practical teaching resources which is connected with the production process, organically combines the discipline chain with the industrial chain, and revolves around the goals of applied talents' knowledge, ability and quality. Cooperate with the enterprise resources to complete the teaching. The excellent managers can be introduced into the classroom, or the classroom can be extended to the enterprise observation. Students can also realize the effective docking between the students and the employment post through the enterprise training in the campus.

\section{Conclusion}

In a word, the Management is the basic course of economics and management specialty, and the traditional teaching method cannot meet the needs of teaching in the new period. Under the background of the applied curriculum reform, the management course needs to change its ideas. It is necessary to construct teaching team, strengthen the construction of characteristic courses, apply diversified teaching methods, strengthen the precision of course design, apply diversified teaching strategies and examination methods, create special courses, improve students' ability of knowledge application, Ability of innovation, etc., to reach the goal of management course.

\section{References}

[1] Yanxia Zhao, Zhenyu Lu, Yali Li. On the Teaching Optimization and Characteristic Curriculum Construction based on Applied Management [J]. Journal of North China University of Technology (Social Sciences Edition), 2016, 16 (5): 120-123.

[2] Ting Sun. On a Probe into the Reform of Undergraduate Teaching Practice of Applied Specialty Courses in Colleges and Universities from the Perspective of Ability Cultivation: Taking the Public Management Specialty as an Example [J]. Research on Ethnic Higher Education, 2016,4 (2): 74-77.

[3] Fenlan Mao,LinxiShi. On the Reform and Exploration of the Teaching Methods of Public Administration Specialty under the Background of the Transformation of Local Applied Universities [J]. Journal of Science and Education, 2017 (3): 79-81.

[4] Linbo Si, Zhongqi Xie, Chunlin Li. Case Teaching Model of Teamwork Based on the Cultivation of Cooperative Ability--A Case Study of Undergraduate Courses in Public Administration [J]. Teaching Research, 2014, 37 (5): 25-29.

[5] Rong Li. On the Principle of Course Reform of Management Based on the Cultivation of innovative ability [J]. Sichuan Labor Security, 2018 (S1): 98+97

[6] Yuhuan Yu. On the Teaching Reform Model of Management Principles Based on the Cultivation of Students’ Professional Ability [J].A Comparative Study of Cultural Innovation, 2018 (14). 